\title{
Isolation of Candida rugosa lipase isoforms
}

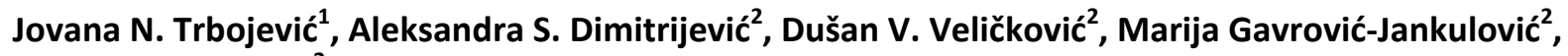 \\ Nenad B. Milosavić ${ }^{2}$ \\ ${ }^{1}$ Innovation Center of Faculty of Chemistry, University of Belgrade, Serbia \\ ${ }^{2}$ Faculty of Chemistry, University of Belgrade, Serbia
}

\begin{abstract}
The yeast Candida rugosa is a convenient source of lipases for science and industry. Crude preparation of Candida rugosa lipase (CRL) consists of several extracellular lipases. Isoenzyme profile depends on the culture or fermentation conditions. All isoforms are coded by the lip pseudogene family; they are monomers of 534 amino acids and molecular weight of about $60 \mathrm{kDa}$. They share the same catalytic mechanism and interfacial mode of activation. Isoenzymes differ in isoelectric points, post-translational modifications, substrate specificity and hydrophobicity. The presence of different lipase isoforms and other substances (i.e., inhibitors) in crude preparation leads to lack of their productivity in biocatalytic reactions. Purification of specific isoform improves its overall performance and stability. This paper provides an overview of different methods for purification of CRL isoenzymes up to date, their advantages and disadvantages.
\end{abstract}

Keywords: Lipases, Candida rugosa, isoforms, purification.

PROFESSIONAL PAPER

UDC 663.12:577.152.311:66.097.3:60

Hem. Ind. 67 (5) 703-706 (2013)

doi: 10.2298/HEMIND120828113T

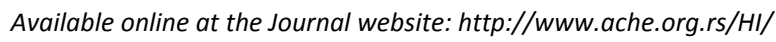

Lipases (E.C.3.1.1.3, glycerol ester hydrolase) catalyze the hydrolysis of an ester bond between a fatty acid and glycerol. They are among the most important biocatalysts in modern science and industry. Many plant, animal and microbial cells produce lipases. Microbial lipases (fungal, bacterial or yeast) have more importance over animal and plant lipases, because they can be easily grown on inexpensive agricultural waste materials: sugarcane, plant or animal fats and oils, etc. [1-6].

Yeast Candida rugosa (formerly known as Candida cylindracea) is a non-sporogenic, pseudofilamentous, unicellular yeast and imperfect hemiascomycete. It grows aerobically in nutritive media with different carbon and nitrogen source. C. rugosa is non-pathogenic microorganism, and its lipases do not show genotoxic or cancerogenic effects on human health. Because of that, the species is generally regarded as safe (it has GRAS status), and classified as biological safety level 1 [7-9].

CRL are decoded by lip pseudogene family. Each isoenzyme is a product of the expression of an individual gene, and each of the lip genes is transcriptionally active [7]. C. rugosa can produce 5-7 lipase isoforms, depending on the culture or fermentation conditions. All of them are glycosylated monomers of 534 amino acids and approximate molecular weight of $60 \mathrm{kDa}$ and have the same catalytic triad (Ser, His, Glu or Asp). Iso-

Correspondence: N.B. Milosavić, Faculty of Chemistry, University of Belgrade, Serbia.

E-mail: nenadmil@chem.bg.ac.rs

Paper received: 28 August, 2012

Paper accepted: 3 December, 2012 enzymes differ in their isoelectric points, carbohydrate content, substrate specificity and hydrophobicity.

C. rugosa lipases are very important biocatalytic tool in different fields of industry (food processing, cosmetic and pharmaceutical preparations, biodiesel production and detergent industry) and science (environmental sciences, analytical chemistry and medicine) [10-17].

\section{EXPERIMENTAL}

Crude preparation of CRL is a mixture of several different lipases and esterases. Activity of one of these enzymes affects the others in the preparation (i.e., in a competitive way), so it is necessary to purify the individual isoform in order to improve its catalytic properties [18].

\section{Multi-step approach}

Pernas et al. purified an esterase of about $43 \mathrm{kDa}$ and reported separation of lipase isoforms 2 and 3 from crude CRL preparation [19]. The crude sample was prepared in two ways: in the first preparation, the sample was simply dissolved in buffer and centrifuged. That supernatant was subjected to hydrophobic interaction chromatography (HIC) on phenyl-sepharose, followed by anion-exchange chromatography on DEAEsephacel and gel-filtration on sephacryl S-200. The second preparation was slightly different, since the crude sample was dissolved in a buffer that contains ammonium sulphate. After stirring and centrifugation, obtained supernatant was subjected to HIC on phenylsuperose HR5/5, followed by anion-exchange chroma- 
tography on Source $15 Q$ HR5/5 and gel-filtration on sephacryl S-200.

Sailas and Pandey described purification method for three distinct fractions of lipases from crude fermentation material, designated as lipase A, B and C [20]. The purification scheme consists of: ammonium-sulphate precipitation, dialysis, ultrafiltration and gel-filtration on sephadex G-200.

Combining chromatography on agarose-mercurial column and desalting step on sephadex G-25, Tai et al. reported separation of two main lipase fractions from crude sample [21].

Combination of anion-exchange chromatography on DEAE-Sepharose CL-6B and "hydrophobic interfacial affinity chromatography" resulted in fine resolution of CRL isoenzymes, according to Xin et al. [22]. The anionexchange step serves for crude separation of two main lipase fractions: CRL A and CRL B. HIC on nucleosil C4 column allowed fine separation of different isoforms, present within the main fractions. Accordingly, both CRL A and CRL B were further resolved to 4 isoenzymes, which slightly differ in their hydrophobicity pattern and hence cannot be separated by conventional HIC methods (i.e., HIC on phenyl-sepharose). In isoelectric focusing, however, CRL A fraction only gave a single band of approximate $p l=5.6$ and CRL B fraction also gave a single band of an approximate $p l=4.2$.

Lipase 3 isoenzyme is reported to act on cholesteryl-esters. In order to investigate its activity on different plant steryl-esters it was necessary to obtain it from crude preparation. Tenkanen et al. describe a method for purification of this lipase isoform, based on combination of classical pre-purification procedure, HIC on phenyl-sepharose FF and ion-exchange chromatography on DEAE-Sepharose [23].

Blends of alginate and gelatin, additionally functionalized with succinic anhydride, can be used for separation of lipases, according to procedure described by Fadnavis et al. [24].

\section{One-step approach}

In recent years there has been a growing interest for developing new, more economic one-step purification strategies. In the further text, some of them will be presented.

Lv and associates have reported a one-step method for successful resolution of Candida $s p$. lipase into four distinct fractions [26]. In this approach, they used ionexchange chromatography on polyethyleneimine monoliths.

Solanki and Gupta [26] have reported simultaneous immobilization and purification of $\mathrm{CRL}$, for the use in tranesterification. Lipase was adsorbed on a $\mathrm{Fe}_{3} \mathrm{O}_{4}$ nanoparticles and coated with polyethyleneimine (PEI). It is believed that purification is achieved because of selective binding property of PEI.

\section{RESULTS AND DISCUSSION}

The general advantage of a multi-step purification approach is that there are well established purification protocols, which are freely available. Also, a great advantage is the use of classic purification techniques, such as ion-exchange chromatography, HIC, gel-filtration, precipitations, etc.

On the other hand, the main disadvantage of such purification methods is the low yield of purified isoenzymes. Table 1 summarizes some of the previously mentioned methods with purification yields. According to data from the table, the highest yield is achieved after purification strategy described in literature [20]. However, in terms of industrial use, the yields are too low, so the described methods are not profitable for large-scale production. Apart from the low yield, the duration of purification process is also a problem, because at least 3 steps are needed for purification of an isoenzyme of interest.

One-step purification methods are convenient for modern approach in isolation of lipases from their sources. They are usually easy to perform, fast and

Table 1. Purification yields of different multi-step purification strategies

\begin{tabular}{|c|c|c|c|}
\hline Purification steps & Purified isoenzyme & Yield, \% & Reference \\
\hline \multirow[t]{2}{*}{ Precipitation, sodium-cholate treatment, ethanol/ether, anion-exchange } & Lip 2 & 4.3 & 19 \\
\hline & Lip 3 & 4.9 & \\
\hline \multirow[t]{3}{*}{ Ammonium-sulphate precipitation, dialysis, ultrafiltration, gel-filtration } & Lip A & 11.62 & 20 \\
\hline & Lip B & 1.15 & \\
\hline & Lip C & 3.64 & \\
\hline \multirow[t]{3}{*}{ Chromatography on agarose-mercurial column } & CRL I & Not defined & 21 \\
\hline & CRL II & & \\
\hline & CRL III & & \\
\hline \multirow[t]{2}{*}{ Ion-exchange chromatography, hydrophobic interfacial affinity chromatography } & CRL A & Not defined & 22 \\
\hline & CRL B & & \\
\hline Pre-purification, HIC, ion-exchange & Lip 3 & 7 & 23 \\
\hline
\end{tabular}


inexpensive. In the term of yield, the represented onestep strategies are compared in Table 2.
172049, 046010 and 451-03-00605/2012-16/51 ) and FP7 Reg Pot FCUB ERA, GA No. 256716.

Table 2. Purification yields of different one-step purification strategies

\begin{tabular}{|c|c|c|c|}
\hline Purification steps & Purified Isoenzyme & Yield, \% & Reference \\
\hline \multirow[t]{4}{*}{ Ion-exchange chromatography on polyethyleneimine monolith } & Lipase A & 3.50 & 25 \\
\hline & Lipase B & 19.8 & \\
\hline & Lipase C & 16.6 & \\
\hline & Lipase D & 12.3 & \\
\hline Simultaneous immobilization and purification & Not defined & Not defined & 26 \\
\hline
\end{tabular}

\section{CONCLUSION}

Within the last decade, interest for microbial lipases, especially those produced by C. rugosa, has increased and will probably continue in that trend even more so in the future. Because of their numerous applications, especially in different fields of industry, it is necessary to find a way to purify these valuable biocatalysts from the crude preparations, which are most commonly used as starting material. Purification increases biocatalytic performances of an enzyme, since it is released from impurities, which can have inhibitory effects on its activity. Having in mind different approaches, described in this paper, it is possible to conclude what their advantages or disadvantages are.

Different multi-step methods have been described and developed, but their major disadvantage is a great loss in the yield during several purification steps. This disables the use of such approaches in large-scale purification, since it is expensive, time-consuming and gives poor yield of the enzyme of interest.

One-step approaches have also been developed. They are less time consuming, but not all of them are cost-effective, since some of them use expensive affinity ligands, or matrices, which cannot be used in largescale production. The purification yield of such approaches can be improved by developing new, more selective purification procedures.

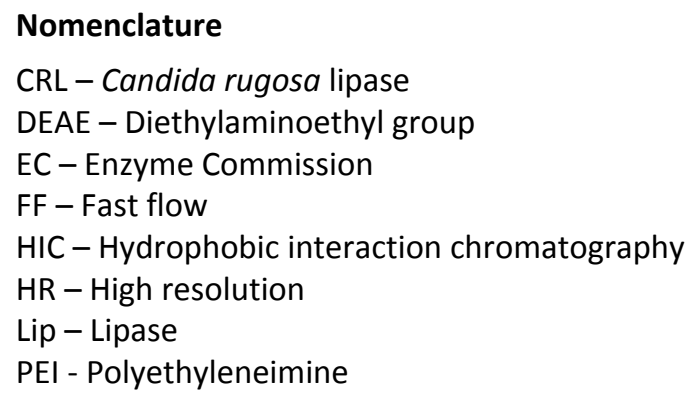

\section{Acknowledgments}

The authors are grateful for the financial support of the Ministry of Education, Science and Technological Development of the Republic of Serbia (Project Nos.

\section{REFERENCES}

[1] K. Long, Unlocking the miracle of lipase, Research Inaugural Lecture Presented at MARDI, Serdang, 2010, pp. 1-46.

[2] M.M. Zheng, Y. Lu, L. Dong, G. Ping-Mei, D. Quian-Chun, L. Wen-Lin, F. Yu-Qi, H. Feng-Hong, Immobilization of Candida rugosa lipase on hydrophobic/strong cation exchange silica particles for biocatalytic synthesis of phytosterol esters, Biores. Technol. 115 (2012) 141-146.

[3] A. Rajan, D.R. Soban Kumar, A.J. Nair, Isolation of a novel alkaline lipase producing fungus Aspergillus fumigatus MTCC 9657 from aged and crude rice bran oil and quantification by HPTLC, Int. J. Biol. Chem. 5 (2011) 116-126.

[4] K.J. Patil, M.Z. Chopda, R.T. Mahajan, Lipase biodiversity, Ind. J. Sci. Technol. 4 (2011) 971-982

[5] L.L. Lock, V.A. Corbellini, P. Valente, Lipases produced by yeasts: powerful biocatalysts for industrial purposes, Techno-Logica 11 (2007) 18-25

[6] B. Dias Ribeiro, A. Machado de Castro, M.A. Zarur Coelho, D.M. Guimaraes Freire, Production and use of lipases in bioenergy: a review from the feedstocks to biodiesel production, Enz. Res. (2011), doi: 10.4061/ /2011/615803.

[7] B. Sailas, P. Ashok, Candida rugosa lipases: molecular biology and versatility in biotechnology, Yeast $\mathbf{1 4}$ (1998) 1069-1087.

[8] M.T. Flood, M. Kondo, Safety evaluation of lipase produced from Candida rugosa: summary of toxicological data, Reg. Toxicol. Pharmacol. 33 (2001) 157$-164$.

[9] http://www.bcrc.firdi.org.tw/fungi/fungal_detail.jsp?id= FU200802060045 (accessed 12 July, 2012).

[10] F. Kartal, A. Kilinc, S. Timur, Lipase biosesnsor for tributyrin and pesticide detection, Int. J. Environ. Analyt. Chem. 87 (2007) 715-722.

[11] J.F. Liang, Y.T. Li, V.C. Yang, Biomedical application of immobilized enzymes, J. Pharm. Sci. 89 (2000) 979-990.

[12] A.A. Khan, M.A. Alzohairy. Recent advantages and applications of immobilized enzyme technologies: A review, Res. J. Biol. Sci. 5 (2010); 565-575.

[13] M.R. Talukder, J.C. Wu, L. Pen-Lin Chua, Conversion of waste cooking oil to biodiesel via enzymatic hydrolysis followed by chemical esterification, Energ. Fuel. 24 (2010) 2016-2019. 
[14] A. Rajendran, A. Palanisamy, A. Thangavelu, Lipase catalyzed ester synthesis for food processing industries, Braz. Arch. Biol. Technol. 52 (2009) 207-219.

[15] http://www.epa.gov/greenchemistry/pubs/pgcc/winner s/gspa09.html (accessed 12 July 2012).

[16] P. Winayanuwattikun, C. Kaewpiboon, K. Piriyakananon, W. Chulalaksananukul, T. Yongvanich, J. Svasti, Immobilized lipase from potential lypolitic microbes for catalyzing biodiesel production using palm oil as feedstock, Afric. J. Biotechnol. 10 (2011) 1666-1673.

[17] S. Zhu, Y. Wu, Z. Yu, Immobilization of Candida rugosa lipase on a $\mathrm{pH}$-sensitive support for enantioselective hydrolysis of ketoprofen ester, J. Biotechnol. 116 (2005) 397-401.

[18] C.C. Akoh, G.C. Lee, J.F. Shaw, Protein engineering and applications of Candida rugosa lipase isoforms, Lip. 39 (2004) 513-526.

[19] M.A. Pernas, C. Lopez, L. Pastrana, M.L. Rua, Purification and characterization of Lip2 and Lip3 isoenzymes from a Candida rugosa pilot-plant scale fed-batch fermentation, J. Biotechnol. 84 (2000) 163-174.

[20] B. Sailas, P. Ashok, Isolation and characterization of three distinct forms of lipases from Candida rugosa produced in solid state fermentation, Braz. Arch. Biol. Technol. 43 (2000) 453-460.
[21] D.F. Tai, Y.F. Chang, T.W. Chiou, Purification of Candida rugosa lipase on agarose-mercurial coloumn, J. Chin. Chem. Soc. 49 (2002) 957-960.

[22] J.Y. Xin, Y.X. Hu, J.R. Cui, S.B. Li, C.G. Xia, L.M. Zhu, Fine separation and characterization of Candida rugosa lipase isoenzymes, J. Basic Microbiol. 42 (2002) 355-363.

[23] M. Tenkanen, H. Kontkanen, R. Isonemi, P. Spetz, B. Holmbom, Hydrolysis of steryl esters by a lipase (Lip 3) from Candida rugosa, Appl. Microbiol. Biotechnol. 60 (2002) 120-127.

[24] N.W. Fadnavis, G. Sheelu, B. Mani Kumaar, M.U. Bhalerao, A.A. Desphande, Gelatin blends with alginate: gels for lipase immobilization and purification, Biotechnol. Prog. 19 (2003) 557-564.

[25] G. Bassani, P. Fucinos, G. Pico, B. Farruggia, Candida rugosa lipase Lip1-polyethyleneglycol interaction and the relation with its partition in aqueos and two-phase system, Colloids Surfaces, B 75 (2010) 532-537.

[26] Y.Q. Lv, D.Y. Fu, T.W. Tan, M.Y. Wang, One-step purification of YLLIP2 isoforms from Candida sp. 99-125 by polyethyleneimine modified poly(glycidyl methacrylateco-ethyleneglycol dimethacrylate) monolith, J. Mol. Catal., B 62 (2010) 149-154.

[27] K. Solanki, M.N. Gupta, Simultaneous purification and immobilization of Candida rugosa lipase on superparamagnetic $\mathrm{Fe}_{3} \mathrm{O}_{4}$ nanoparticles for catalyzing trancesterification reactions, New J. Chem. 35 (2011) 2551-2556.

\section{IZVOD}

\section{IZOLOVANJE IZOFORMI LIPAZE IZ Candida rugosa}

Jovana N. Trbojević ${ }^{\text {, Aleksandra S. Dimitrijević }}{ }^{2}$, Dušan V. Veličković ${ }^{2}$, Marija Gavrović-Jankulović ${ }^{2}$, Nenad B. Milosavić ${ }^{2}$ ${ }^{1}$ Inovacioni Centar Hemijskog fakulteta, Univerzitet u Beogradu

${ }^{2}$ Hemijski fakultet, Univerzitet u Beogradu

\section{(Stručni rad)}

Lipaze (hidrolaze estara glicerola, E.C.3.1.3.3) su važna grupa enzima, široko rasprostranjenih u prirodi. Mogu se izolovati iz materijala biljnog, životinjskog ili mikrobnog porekla. Zahvaljujući svojim karakteristikama, pobuđuju sve više pažnje kao efikasni biokatalizatori u različitim sintetičkim i hidrolitičkim procesima. Među lipazama, poreklom iz mikroorganizama, posebno su značajne one koje produkuje kvasac Candida rugosa. Komercijalni preparat lipaza iz C. rugosa može sadržati 5-7 izoformi ekstracelularnih lipaza. Sve te izoforme kodirane su od strane lip familije pseudogena, a na njihovu ekspresiju utiču uslovi u kojima se mikroorganizam gaji (sastav hranljive podloge je najvažniji). Ekstracelularne lipaze, koje proizvodi $C$. rugosa su monomerni glikoproteini, molekulske mase od oko 60 $\mathrm{kDa}$, sa 534 aminokiseline. Za sve izoforme je karakterističan isti složeni mehanizam aktivacije na granici faza i mehanizam katalize, kakav se sreće i kod serin-proteaza. Izoenzimi se međusobno razlikuju po post-translacionim modifikacijama (udelu ugljohidratne komponente), supstratnoj specifičnosti, izoelektričnim tačkama i hidrofobnosti. Prisustvo više izoformi lipaza u komercijalnom preparatu utiče na njihovu produktivnost u reakcijama koje katalizuju. Takvi preparati često sadrže i druge supstance koje mogu uticati na aktivnost enzima (na primer inhibitore). Razdvajanjem pojedinačnih izoformi iz komercijalnog preparata poboljšavaju se njihova enantioselektivnost, specifična aktivnost i stabilnost enzima, što je od izuzetnog značaja za njihovu dalju primenu. $U$ ovom radu su predstavljeni različiti pristupi u razdvajanju pojedinačnih izoformi vanćelijskih lipaza iz komercijalnog preparata C. rugosa, njihove prednosti i nedostaci.
Ključne reči: Lipaze • Candida rugosa • Izoforme • Prečišćavanje 